
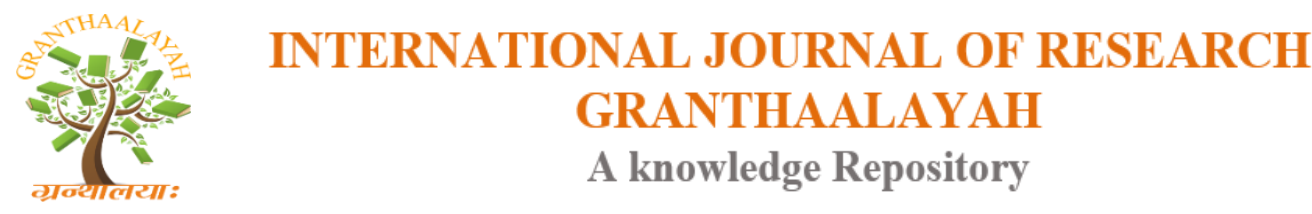

Science

\title{
ACHIEVEMENTS AND PROBLEMS OF ELECTRODE MODIFICATION FOR VOLTAMMETRY
}

\author{
Gavkhar Narmaeva ${ }^{1}$, Sergei Aronbaev ${ }^{1}$, Dmitry Aronbaev ${ }^{1}$ \\ ${ }^{1}$ Department of Chemistry, Samarkand State University, Samarkand 140104, Uzbekistan
}

\begin{abstract}
In a review article, the achievements and problems of modifying carbon-containing electrodes for voltammetric analysis are considered.

Various methods for chemical modification of electrodes are described, including methods of surface modification, volumetric modification, impregnation by in-situ and ex-situ methods. It is noted that modified electrodes with a catalytic response are increasingly used in voltammetry. This is explained by the fact that in a number of cases the catalytic currents that are caused by the included or previous chemical reaction far exceed the limiting diffusion currents, which makes it possible to increase the sensitivity of the method and to lower the lower limit of the determination by several orders of magnitude.

Examples of the use of chemically modified carbon-containing electrodes in the voltammetric analysis of inorganic ions and organic substances are given.
\end{abstract}

Keywords: Voltammetry; Carbon-Containing Electrodes; Chemically Modified Electrodes; Modification Methods; Surface and Volumetric Modification; Catalytic Response; Application in Analysis.

List of Accepted Acronyms (Abbreviation): CME - chemically modified electrode; CG glassy carbon; CSC - chemical sources of current ; ISV- inversion stripping voltammetry.

Cite This Article: Gavkhar Narmaeva, Sergei Aronbaev, and Dmitry Aronbaev. (2018). "ACHIEVEMENTS AND PROBLEMS OF ELECTRODE MODIFICATION FOR VOLTAMMETRY." International Journal of Research - Granthaalayah, 6(7), 368-381. https://doi.org/10.29121/granthaalayah.v6.i7.2018.1316.

\section{Introduction}

At present, it has become obvious that the use of chemically modified electrodes will solve a number of acute problems of voltammetry and unlimitedly expand the analytical capabilities of electrochemical analysis methods.

When modifying on the surface of the electrode, chemical compounds or polymer films are applied which significantly change its ability to voltammetric response: electron transfer proceeds at a high 
speed and with a small overvoltage. In general, the term chemically modified electrode (CME) is now referred to any electrode whose surface has been treated in this way (by physical or chemical means), which changes the nature of the electrochemical respons [1].

The modification of electrodes, which has become widespread in the production of electrochemical sensors, chemical sources of current (CSC), electrocatalysis, etc., is based on physical methods, including the growth of single crystal faces, ion implantation, the creation of single crystal structures, surface loosening, physical adsorption, etc. chemical methods. CMEs are a material with conductive or semiconducting properties, coated with monomolecular (also subatomic), polymolecular, polymer, ionic layers, for this reason, the electrode exhibits electrochemical, chemical and / or optical properties of the layer. Chemical modification of the electrode is achieved by chemisorption on its surface of molecules and ions, covalent binding of various agents to surface atomic groups, surface coating with inorganic, organometallic or organic polymeric layers, creating composites from electrode material and a modifier $[2 ; 3 ; 4]$.

The electrodes are modified by different methods. The substance can be retained on the surface by chemisorption, the monolayer can be formed by covalent bonding to the surface; Polymers with electrochemically active groups can be deposited on the surface, electrostatically attracting the mediator to the surface.

The cause of spontaneous modification of electrodes is often strong adsorption. A similar, often undesirable, phenomenon has found practical application in electroanalytical methods. As a rule, electrodes modified by adsorption have insufficient stability so that they can be used universally, since the desorption process proceeds to them relatively easily. More stable types of CME are obtained using reagents, the functional groups of which with the electrode material are capable of forming covalent bonds. Most often, compounds with oxygen-containing groups (oxy, carboxy or hydroxy groups) are used, however, there are other methods of modification [5].

CME is created by immobilizing on the surface of a conductive base organic compounds of various types. This makes it possible to synthesize systems with specific catalytic and adsorption properties, which, primarily, are due to the functional groups of the organic compound. CME are one of the examples of practical application of the phenomenon of irreversible adsorption of organic substances on d-metals [6].

The aim of the paper is to consider the methods of chemical modification of carbon-containing electrodes and their analytical application in the voltammetric determination of inorganic ions and organic substances.

\section{Methods for Modifying Electrodes}

In the electrochemical system, the signal-response of the sensor is formed at the interface between the phases of the electrode solution and depends on the state of the surface of the electrode, which is determined by the nature of the material, its homogeneity, the presence of modifying substances, etc. [7]. 
Therefore, the success of measurements depends on the correct choice of the indicator electrode: the magnitude and reproducibility of the analytical signal. As a result, considerable attention has been paid to the material of the electrodes, the methods for their chemical and physical modification, methods of regeneration and expansion of the working region of the potentials.

The general scheme of electrode modification options is shown in Figure 1.

When modifying the electrodes in situ, the modifier is dissolved in the solution to be analyzed. Wide application this method found in inversion streeping voltammetry (ISV).

As modifiers, metals (cadmium, copper, mercury, bismuth, etc.) are used to facilitate the precipitation of electropositive and amalgam-forming elements, water-soluble organic compounds, for example, biologically active substances, ligands. polymers. Sometimes combinations of different modifiers are also used: polymer and metal, polymer and ligand, metal and ligand, etc.[8].

Another way to modify electrodes in situ is to introduce into the solution organic molecules that are capable of self-organization on the electrode surface. They create ordered monolayers that change the transport of depolarizer particles to the electrode not only due to differences in sizes and charges, but also due to the hydrophobic effect. Thus, co-carboxylic acids form on the mercury surface of Langmuir-Blodge films, which consist of close-packed molecules that lie orthogonally to the surface of the electrode. This self-organization is used in the modification of gold electrodes. In this case, long chain hydrophobic molecules with terminal thiol groups forming an $\mathrm{Au}-\mathrm{S}$ bond with the electrode are the modifiers. The regularity of the structure is provided by hydrophobic interactions of hydrocarbon radicals.

The fixing of the modifier on the electrode surface, as a rule, is carried out by adsorption. The advantage of in situ modification methods is that they do not require the addition of modifier molecules to the electrode. Sufficient is, before modification, the cleaning of the surface from the products of the electrochemical reaction.

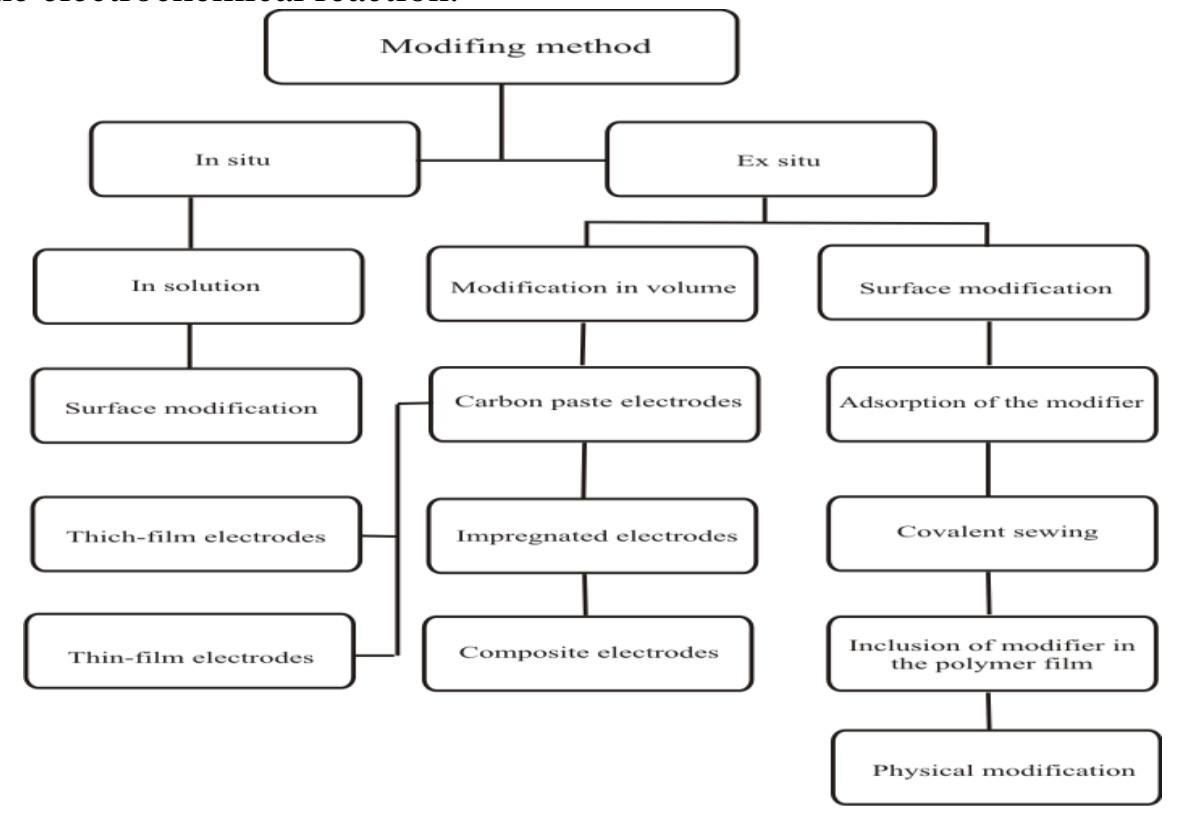

Figure 1: Methods electrodes modification 
However, the lifetime of such electrodes is comparatively small, since before every measurement it becomes necessary to carry out a modification again.

As an alternative to in situ modification methods, methods for the preliminary immobilization of modifiers (ex situ) on electrodes of various materials, such as: glassy carbon (GC), metals, pyrographite, carbonite, have been developed and widely used. composite materials, impregnated graphite, carbon mesh, carbon paste, yarn, fibers, etc. A combination of their properties allows creating electrodes with specified sensitivity and selectivity parameters.

Preliminary modification separates the processes of preparation of the modifying layer (electrode) and directly measurements of the analytical signal. On the one hand, this makes it possible to standardize the modified electrode before measurement, for example, in preparation for a field experiment in the laboratory. In addition, the immobilization of the ex situ modifier shortens the measurement procedure and avoids gross errors due to the human factor. On the other hand, the preliminary modification makes higher demands on the stability of the modified coating. Most in situ methods are generally similar to the preliminary modification of the electrode, therefore it makes sense to consider in more detail the general approaches to electrode modification $[9 ; 10 ; 11 ; 12]$.

\section{Volumetric Modification of Electrodes}

The introduction of a modifier directly into the working electrode material is the most understandable and simple modification method, which ensures the constancy of the electrode material composition, and at the same time the contact of the modifier with the electrically conductive base and the solution being analyzed. Although volumetric modification has no fundamental limitations on the material of the electrode, the application has mainly found electrodes based on graphite materials.

The greatest distribution among volumetric carbon-containing electrodes was produced by carbonpaste electrodes (CPE). In the simplest case, the CPE repeats the shape of a traditional monolithic electrode - a graphite or metal rod. It is a cylinder made of carbon paste, enclosed in a hollow shell of insulating material - a tube of plastic or glass, which plays the role of a reservoir of paste and determines the geometric dimensions of the electrode - the area of the end of the cylinder. Such electrodes are characterized by a relatively large ratio of the volume of the carbon paste to the area of the working surface of the electrode. Actually, only a small part of the electrode substance that is in contact with the analyzed solution participates in charge transfer. This design of the electrodes has both advantages and disadvantages. The first relates to the relative simplicity of manufacturing. Mixing sufficiently large amounts of components makes it possible to achieve homogeneity of the paste, even with manual mixing, and in order to regenerate the active surface of the electrode, it is sufficient to remove the surface thin layer. The large volume of the electrode makes it possible to repeat this procedure dozens of times, obtaining a stable and reproducible response. The surface can be mechanically renewed by cutting a thin layer of paste protruding from the insulating tube with a sharp knife. Such a method is often used for small-diameter electrodes or for plastic pastes, whose mechanical grinding is not allowed. 
The second variant of the CPE design is a device resembling a syringe, in which the current collector is also a piston. When it is moved from the insulating tube, a small amount of paste is squeezed out, which is then removed. It is possible to adjust the piston stroke mechanically, provided that the rod is connected to the electrode by a thread $[13 ; 14 ; 15]$.

Grinding the surface of the electrode is necessary not only to update the surface layer. With this procedure, a certain roughness of the surface is achieved, this ensures the reproducibility of the ratio of the geometrical and true surface area of the electrode, as well as the response signal. Sometimes grinding is accompanied by a partial melting of the filler, which fills the pores, thus reducing the porosity of the electrode, and, consequently, undesirable processes of electrolyte entering it. At the same time, the charging current decreases and the shape of the peaks on voltammograms improves. Grinding also contributes to the partial oxidation of active surface groups of graphite materials and fillers. Oxidation of metal particles can occur to form oxides. The influence of the above factors on the characteristics of voltammograms depends on the nature of the Faraday processes and the characteristics of the system modifier-the substance being determined.

The production of a bulk macroelectrode is associated with a relatively high modifier flow rate. One option to avoid this, especially at the stage of selection of the optimal composition of carbon paste - used as a glassy carbon electrode rod into the insulating jacket, which is made in the end of a small conical indentation or hemispherical shape. The groove is filled with carbon paste, its volume is several tens of microliters [16].

After measuring, the paste is removed from the groove, after which it is filled with a new portion of the paste. Given that work with such electrodes is more complicated than with conventional makroelektrodom, its use is justified when using expensive or unstable modifiers, for example, in biosensors based on nucleic acids, antibodies, enzymes, and others.

The volumetric microelectrode is a glass or plastic capillary, the tip of which is filled with a modified electrically conductive material that is retained inside the electrode by capillary forces. The current collector is a thin metal wire that is inserted into the paste from the opposite end of the capillary. Similar electrodes are used to determine the content of electrochemically active components in biological tissues or intracellular fluid of living organisms [8].

\section{Impregnated Electrodes}

Often electrodes from carbon or spectral graphite impregnated with a certain filler are used, which is most often used as polyethylene, paraffin, petrolatum, suitable resins or mixtures of these substances.

If we take into account the peculiarities of carrying out electrocatalytic reactions and the method of synthesis of CME, it can be concluded that carbon materials possessing high chemical stability, electrical conductivity, and a wide range of various functional groups on the surface are certainly convenient carriers for the creation of CME. Currently, only a fraction of the possible methods of synthesizing CME are realized. and further we will consider those that have been used to create carbon-modified electrodes. 
Figure 2 shows the basic schemes of planting metal complexes on the surface of carbon materials.

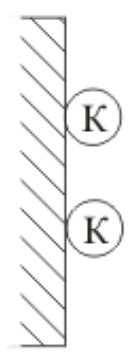

1

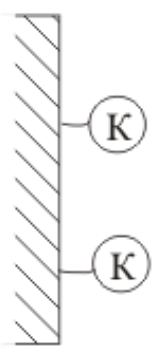

2

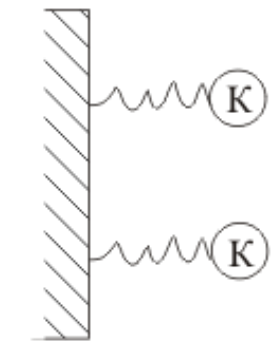

3
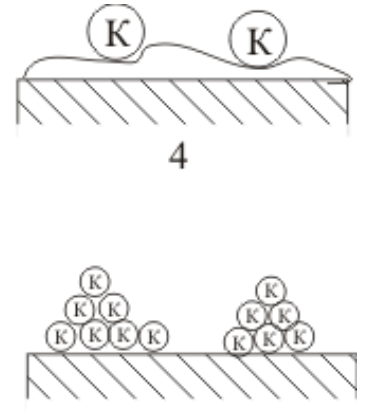

5

Figure 2: Scheme of planting metal complexes on the surface of carbon materials

The first variant corresponds to adsorption bonding, the second one corresponds to chemical "sewing" to the surface group, the third characterizes the chemical binding through the "leg", the fourth one corresponds to adsorption immobilization on the sublayer, for example, the polymer, the fifth corresponds to the formation of a microcrystal or promoter cluster [17].

According to the data of [18], the complex compound, iron and cobalt porphyrins are adsorbed on pyrography from solutions in dimethylformamide and dichloromethane [19].

The ability of graphite electrodes to strongly adsorb aromatic molecules was used to bind the complex $\left[\mathrm{Ru}\left(\mathrm{NH}_{3}\right)_{5} \mathrm{~L}\right]^{2+}$, where $\mathrm{L}$ is a large aromatic ligand, for example, 4-aminomethylpyridine or M- (4-picoline) benzamide [20]. A complex of [(Ru (bpy) $\left.\left.{ }_{2}\right)_{2} \mathrm{~L}\right]^{2+} \cdot 2\left(\mathrm{PF}_{6-}\right)$ (L-dianion 1,5dihydroxyanthrachnone) was adsorbed on the SS electrode by evaporation of the non-aqueous solution [21].

The adsorption of relatively simple dipyridyl and phenanthroline metal complexes on pyrographite is less pronounced [22].

The next direction of application of the adsorption method is in the preparation of polymer coatings, for example, polyacrylonitrile, which can subsequently coordinate metal ions. Modification of the surface can also be carried out with the help of binding organic substances that do not interact with the electrolyte and do not clog the pores of the carrier, thus maintaining the selectivity of the electrode [23;24].

In the synthesis of modified electrodes, an important role is played by the carrier. Porous adsorption carbon materials such as carbon black, activated carbon, spectrally pure graphite, ash, pyrographite, etc. are widely used as a carrier. Such carriers have the characteristic properties necessary to create new modified electrodes.

\section{Modified Electrodes with Catalytic Response in Voltammetry}

The kinetic phenomena at the electrode-solution interface have always attracted the attention of electroanalysts, since in many cases the currents that are caused by the included or previous chemical reaction far exceed the limiting diffusion currents. At the same time, it becomes possible 
to increase the sensitivity of the method and to lower the lower limit of the definition by several orders of magnitude.

Among the widely used electrode reactions, it makes sense to isolate the currents with the participation of oxidizers in polarography and the catalytic currents of hydrogen evolution [25] on a mercury dropping electrode with an "automatically" renewable surface.

In the case of solid-phase electrodes, there is almost always a problem of updating their surface, with which the reproducibility of measurements is directly related.

In order to reduce the influence of heterogeneous factors, different approaches have been proposed, among which the so-called mediator transfer of an electron, that is, an indirect one, has received visible interest, the surface roughness of the electrode in which other heterogeneous factors have been minimized [26;27]. The catalytic nature of the reaction made it possible to increase the sensitivity of the determination. Nevertheless, the redox mediator system functioned in solution in the presence of an analyte (substrate) and to evaluate the reproducibility in a series of measurements it was removed every time.

Consequently, the search for immobilization options on the electrode surface of redox mediators, which would provide a stable catalytic response to the analyte, was fully justified. At the moment, many CMEs with catalytic response to stable both in stationary solutions and under different liquid flow conditions are described $[28 ; 29 ; 30]$.

It is known that many substances enter the electron transfer reaction with overvoltage, that is, at much more negative or positive potentials than their thermodynamic quantities. One way to reduce this difference is to use red-ox mediators that transfer electrons from the analyte to the electrode or vice versa.

The scheme of the electrode process on such electrodes, for example, in the case of electrooxidation, is as follows: the $\mathrm{M}_{\text {red }}$ mediator enters an electrochemical reversible reaction with the formation of $\mathrm{M}_{\mathrm{ox}}$ particles that react chemically with the analyte (A) to form products $(\mathrm{P})$ :

$\mathrm{M}_{\text {red. }}-\mathrm{e} \leftrightarrow \mathrm{M}_{\mathrm{ox}}$.

$\mathrm{M}_{\text {ox. }}+\mathrm{A} \leftrightarrow \mathrm{A}^{*}+\mathrm{M}_{\text {red. }}$

$\mathrm{A}^{*} \rightarrow \mathrm{P}$

The transfer of electrons occurs between the electrode and the mediator, and not between the electrode and the analyte. It should be emphasized that the electrochemical conversion to which the analyte undergoes occurs under the formal redox potential of the Mox. / Mred. pair. The regeneration of Mred allows this process to be classified as catalytic. Thus, the decrease in the formal redox potential of the $\mathrm{P} / \mathrm{A}$ system and the increase in the mediator current in the presence of the analyte are observed experimentally compared with the current in the absence of the analyte. Depending on the mechanism, heterogeneous electron transfer reactions, to the same extent as homogeneous ones, can be intraspheric and outer-sphere [31]. If the reversible Mox. / Mred. system performs only the electron transfer function without forming an intermediate complex between the analyte and the catalyst (the redox pair Mox. / Mred.), then they are dealing with 
outer-sphere or redox catalysis. If during the reaction a Mox. a product is formed, this mechanism of electrocatalysis is called chemical or intraspheric catalysis. In this case, in comparison with outer-sphere reactions, energy is lost due to the binding and activation of the analyte. The main role in the catalytic cycle is acquired by transformations of the substrate in the coordination sphere of the catalyst, and therefore this kind of catalysis is also called coordination electrocatalysis [32]. The flow of mediator reactions is possible only if a number of criteria (thermodynamic, electrochemical kinetic, structural) are observed.

For example, it was shown in [33] that an important role is played by the orientation on the surface of copper complexes, which depends on the filling and the type of substituents. The activity reaches a maximum with a small filling and decreases with its increase. This dependence is explained by the fact that if, by analogy with homogeneous catalysis, it is assumed that the electrode surface and the substrate are in the cis-conformation with respect to the central nonadsorbed complex. Under these conditions, synchronous transmission of two electrons in the "g" stage can take place according to the scheme depicted in Fig. 3.

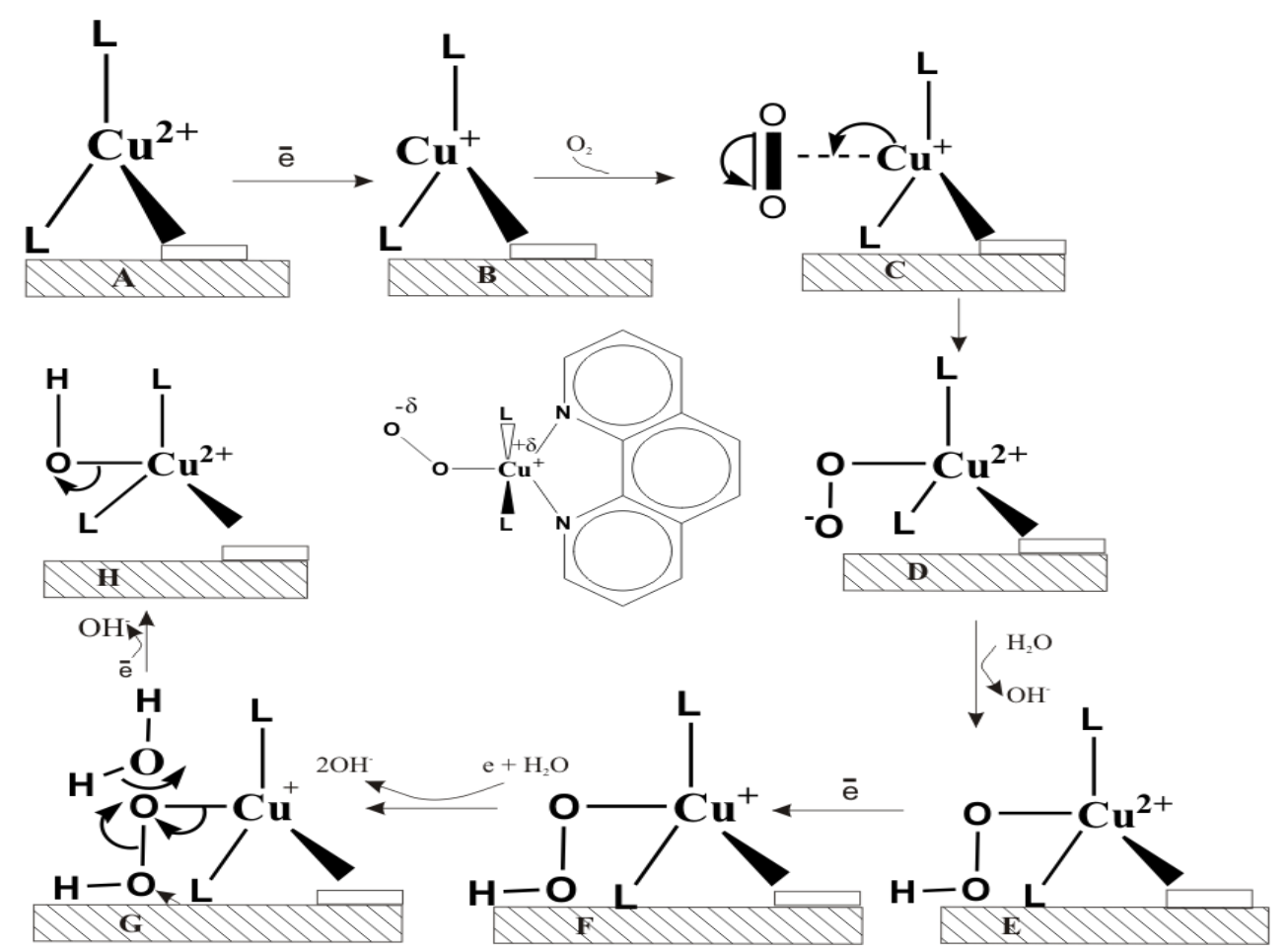

Figure 3: Scheme of transfer of electrons from the electrode to an oxygen molecule in the presence of adsorbed copper.

With an increase in the degree of filling, the possibility of realizing the structure of " $\mathrm{G}$ " decreases and activity decreases. As a result, in the case of phenanthroline copper complexes, the role of a substrate appears in the role of which carbon material appears.

\section{Modified Electrodes in the Voltammetric Determination of Inorganic Ions}

At present, in voltammetry, there is a tendency for mercury electrodes to be displaced by others made of non-toxic materials. In most cases, these are the electrode-containing electrodes, which 
have a number of attractive properties for the determination of ions of various metals. Publications on this subject, respectively, with the type of electrodes used can be divided into six groups [8].

The first group includes works on the practical application of electrodes based on GCE, the second - CPE, the third - composite on the basis of carbon, the fourth - impregnated graphite, the fifth thick-film graphite-containing and printed (screen-printed) electrodes and the sixth ultramicroelectrodes of carbon materials and their ensembles.

Most of the research is devoted to GCE, but in recent years, thin-film planar and thick-film graphite-containing electrodes synthesized by screen and ink-jet methods have attracted interest.

GC electrodes are practically non gas-tight, isotropic, conduct well, have a small porosity and high hardness, are stable in aggressive media. Nevertheless, they have a low adsorption capacity compared to other carbon materials, which explains the relatively low sensitivity of determinations on unmodified electrodes.

As modifiers of GC electrodes, there may be metals ( $\mathrm{Cu}, \mathrm{Ir}, \mathrm{Bi}, \mathrm{Au}, \mathrm{Cd})$, nanotubes, biologically active substances, organic compounds, polymers. Typically, the process of immobilization of water-soluble components on the surface of the electrode is carried out in situ, and soluble - ex situ.

In order to increase the selectivity, a combination of ex situ and in situ regimes is sometimes used. For example, an electrode of an electrically conductive polymer is initially deposited on the electrode, and a selective organic reagent interacting with the detectable ion and adsorbed on the electrode surface is introduced into the solution. Along with this, a two-layer modification of the electrode surface occurs. In some cases, up to three modifying layers can be expanded, each of them fulfilling a specific function. Thus, layer-by-layer modification of the electrode by clay, cation-exchange polymer and mercury makes it possible to synthesize on the surface of the glassy carbon a modifying layer with cation-exchange properties capable of forming amalgam with detectable metals.

CPE show increased adsorption capacity to many substances in comparison with electrodes from GC. This is successfully used in the determination of inorganic ions in voltammetry. The introduction into the paste of the electrode or the immobilization on its surface of compounds containing functional groups specific for the metal ions increases the sensitivity and selectivity of the determinations. The most widely used is the introduction of a modifier into the paste. Often, as modifiers, substances with complexing properties, ion-exchange materials, inorganic and polymeric sorbents: organic reagents, silica, clays, natural and artificial ion exchangers, crowncompounds, heterocyclic compounds act as modifiers. Electrodes based on silica with selfassembled monolayers, which allow determination of $\mathrm{Cd}$, are proposed $\mathrm{Cu}, \mathrm{Pb}$ as well as $\mathrm{CPE}$ modified with $\alpha$ - and $\beta$-cyclodextrins.

The main disadvantage of CPE is the relatively low accuracy of the determinations, which is caused by poor reproducibility of the electrode surface when it is updated. Many chemistsresearchers see the solution of this problem in the use of factory carbon-containing electrodes made with the use of modern technologies and new composite materials, from mechanical processing, 
impregnation of graphite rods in vacuum and finishing with gluing in a plastic case and polishing the surface.

There are also works on the use of electrodes with immobilized nanoparticles for trace analysis of inorganic compounds by the method of inversion voltammetry [34]. In particular, an electrode modified with gold nanoparticles is used to determine arsenic by the IVA method. However, at the moment only the first steps have been taken on the way of using nanoscale metal particles and bimetals in voltammetry.

Nanotechnology opens up new opportunities for developing methods for the synthesis and application of modified electrodes with included mediators. The use of nanostructured materials (nanoparticles of metals, alloys, nanocomposites based on them, nanotubes) made it possible to create electrodes of a new generation. With the help of these electrodes, it is possible to determine such important low-molecular compounds as nitrogen monoxide in biomedical objects, in connection with the fact that this neurotransmitter participates in many physiological processes of the body.

Estimating the prospects for using modified electrodes in the analysis of inorganic compounds, it can be noted that the development of voltammetry as well as other methods of electrochemical analysis is increasingly blending into the development of new electrodes, sensors and sensors that allow for the determination of "cheaper, faster, easier and better." A large number of research works on the search for ways to use and select modifiers, their immobilization on the electrode surface, the use of electronic transfer mediators is undeniably evidence of interest in this problem. Although the phenomenological stage in the conduct of research has not yet ended. Until now, a number of issues have not been resolved that prevent the wide use of modified electrodes. In particular, this applies to the production of electrodes with a stable electrochemical response that does not depend on methods of preparing the electrode surface before the corresponding measurements. Attempts to replace mercury with other metals, for the most part, lead to loss of sensitivity and selectivity of definitions.

The relatively short duration of the "life" of most electrodes, their "aging" with time, which manifests itself in a change in the composition and structure of the modifying layer and the deterioration of its analytical characteristics is another problem. The duration of the electrodes is greatly limited by the need for surface regeneration after each measurement. It is the electrode surface that is the source of most of the problems. Even for a well-studied GC electrode, there is still a discussion about the nature of the mercury film on its surface-whether it is uniform with a thickness of 0.5 to $10 \mu \mathrm{m}$ or whether $\mathrm{Hg}$ is released as fine droplets with a statistical distribution on the surface of the electrode [35;36].

During the creation and application of modified electrodes, it becomes necessary to answer a number of questions: how to make the surface of the modifying layer stable and reproducible, how the properties of the modifying layer affect the parameters of the response signal, how the electrochemical or mechanical surface treatment affects the activity of the modifier and the electrode process: how exclude contamination of the electrode by interfering substances, which impair its analytical characteristics [3;8]. 
Synthesis of modified electrodes for use in various fields of chemical technology is given great attention. The greatest part of the research in this area is devoted to the development of a different type of sensors for voltammetric determination of inorganic and organic substances $[16 ; 37 ; 38 ; 39 ; 40 ; 41 ; 42 ; 43 ; 44 ; 45 ; 46 ; 56 ; 57]$, the creation of fuel cells, electrocatalysis in organic synthesis, etc. $[47 ; 48 ; 49 ; 50 ; 51 ; 52]$.

For modification, porous materials characterized by a developed surface are used as a substrate, often they are carbon-based materials, zeolites and other composite materials are also used $[53 ; 54 ; 55]$.

\section{Conclusion}

Having considered various methods of modification of carbon-containing electrodes, we arrive at the following conclusions:

Chemical modification allows to expand the analytical possibilities and scope of application of voltammetric methods of analysis for the determination of various substances of inorganic and organic origin and to limit the use of mercury-containing electrodes. In the near future, the main task of electrochemical analysis methods is to improve the analytical parameters of the electrodes with a modification of their surface and the possibility of a catalytic response.

\section{References}

[1] Budnikov G.K.(2003). "OSNOVY SOVREMENNOGO EHLEKTROHIMICHESKOGO ANALIZA”. M.: Mir. Binom. Laboratoriya znanii, 592.

[2] Bagockij B.C.(1998). "OSNOVY EHLEKTROHIMII.” M.: Himiya, 400.

[3] Goyal R., Bishnoi S.(2012). "SURFACE MODIFICATION IN ELECTROANALYSIS: PAST, PRESENT AND FUTURE”. Indian Journal of Chemistry-Part A, 51, 205-225.

[4] Brurnbach M., Armstrong N.R.(2007) PREPARATION OF MONOLAYER MODIFIED ELECTRODES . Encyclopedia of Electrochemistry, 10, 5-28.

[5] Martynyuk O. A. (2010). "VOL'TAMPEROMETRICHESKOE OPREDELENIE RYADA LEKARSTVENNYH VESHCHESTV NA TVERDYH I ORGANO-MODIFICIROVANNYH EHLEKTRODAH”. Avt. diss. ...kand.him.nauk. - Tomsk, 24 .

[6] Noskova G. N.(2012). "TVERDYE UGLERODSODERZHASHCHIE KOMPOZITNYE EHLEKTRODY DLYA OPREDELENIYA EHLEMENTOV VOL 'TAMPEROMETRICHESKIMI METODAMI' // Avtoref. diss....dokt.him.nauk. - Tomsk, 43.

[7] "ELEKTROANALITICHESKIE METODY. TEORIYA I PRAKTIKA". (2006). / pod red. F.SHol'ca. M.: Binom. Laboratoriya znanij, 326..

[8] Budnikov G.K., Evtyugin G., Majstrenko V.N.(2012). "MODIFICIROVANNYE EHLEKTRODY DLYA VOL'TAMPEROMETRIN V HIMII, BIOLOGII I MEDICINE”. M.: Binom. Laboratoriya znanij,416.

[9] Budnikova Yu.G. (2002). "METALLOKOMPLEKSNYJ KATALIZ V ORGANICHESKOM EHLEKTROSINTEZE". Uspekhi himii, 2(71),126-158.

[10] Ilovajskij A.I., Merkulova V.M., EHlinson M.N., Nikishin G.I.(2012). "EHLEKTROHIMICHESKI INICIIROVANNYE CEPNYE REAKCII V ORGANICHESKOM SINTEZE". Uspekhi himii, 5(81), 381-396.

[11] EHllert O.G., Codikov M.V., Nikolaev S.A.(2014). "BIMETALLICHESKIE NANOSPLAVY V GETEROGENNOM KATALIZE PROMYSHLENNO VAZHNYH REAKCIJ: SINERGIZM I 
STRUKTURNAYA ORGANIZACIYA AKTIVNYH KOMPONENTOV”. // Uspekhi himii, 8(83),718-732.

[12] Gmoshinskij I.V., Hotimchenko S.A., Popov V.O.(2013). "NANOMATERIALY I NANOTEKHNOLOGIN: METODY ANALIZA I KONTROLYA”. Uspekhi himii, 1(82), 48-76.

[13] Sharath Shankar S., Kumara Swamy B.E., Pandurangachar M.,(2010). "ELECTROCATALYTIC OXIDATION OF DOPAMINE ON ACRYLAMIDE MODIFIED CARBON PASTE ELECTRODE: A VOLTAMMETRIC STUDY"// Int. J. Electrochem Sci., 5, 944-954.

[14] Shahrokhian S., Karimi M., Khajehsharifi H.(2005). "CARBON-PASTE ELECTRODE MODIFIED WITH COBALT-5-NITROLSALOPHEN AS A SENSITIVE VOLTANIMETRIC SENSOR FOR DETECTION OF CAPTOPRIL SENSORS AND ACTUATORS.” Chemical.,109, Issue 2, P. 278-284.

[15] Akram W.(2012). "ELECTRO-OXIDATION OF 4-HYDROXYBIPHENYL AT NBROMOSUCCMIMIDE-MODIFIED CARBON PASTE ELECTRODE”. J. Chem. Soc. Pak. , 4(34), 937-941.

[16] Aronbaev S.D., Narmaeva G.Z., Aronbaev D.M. (2018). "CARBON-CONTAINING ECOLOGICALLY CLEAN ELECTRODES, MODIFIED BY BISMUTH FOR VOLTAMPEROMETRIC ANALYSIS”. Universum: Chemistry and Biology: electronic scientific journal , 5(47). URL: http://7universum.com/ru/nature/archive/item/5782

[17] Craig E.B., Trevor J. D.(2004). "ELECTROCATALYSIS AT GRAPHITE AND CARBON NANOTUBE MODIFIED ELECTRODES: EDGE-PLANE SITES AND TUBE ENDS ARE THE REACTIVE SITES”. Chein. Common, 6(27), 829-841.

[18] Edwards G.A.. Bergen A.J.(2007). "CHEMICALLY MODIFIED ELECTRODES". Iowa state university, 8(9), 296-327.

[19] Seyed N.A., Ghaserni Sh.(2013)."NICKEL MESOPOROUS SILICA MODIFIED ELECTRODE AN EFFECTIVE POROUS MATERIAL FOR ELECTROOXIDATION OF METHANOL". Electrochimica Acta, 6(88), 463-472.

[20] Pimenova A.M.(2006). "EHLEKTROHIMICHESKOE OKISLENIE MEDI, SEREBRA I SPLAVOV SEREBRA-MED' V EHLEKTROLITNYH SISTEMAH NA OSNOVE SERNOJ KISLOTY". Avtoref. ... kand. him. nauk: 05.17.03. - Ivanovo, 20.

[21] CHencova E.V.(2006). "Kineticheskie zakonomernosti formirovaniya ehlektroliticheskih osadkov splavov sistemy Ni-Cu-Zn-Cd". Avtoref. ... kand. him. nauk: 02.00.05. - Saratov, 30..

[22] Savinova E.R. "RAZMERNYE I STRUTSTURNYE EHFFEKTY V EHLEKTROKATALIZE". Avtoref. ... kand. him. nauk: 02.00.15, 02.00.05. - Novosibirsk, 31.

[23] Gmoshinskij I.V., Hotnmchenko S.A.(2013) "NANOMATERIALY I NANOTEKHNOLOGIN: METODY ANALIZA I KONTROLYA" // Uspekhi himii, 1(82), 48-76.

[24] Shajdarova L.G.(2009). "Modificirovannye ehlektrody s kataliticheskimi svojstvami v organicheskoj volyamperometrni”. Diss ... dok. him. nauk: 02.00.02. - Kazan', 350 .

[25] Tur'yan Y. A.(1998). "POLYAROGRAFICHESKAYA KATALIMETRIYA". M.: Himiya, 272.

[26] Budnikov G.K., Kartina O.YU., Abdullin I.F.(1989). "PERENOSCHIKI EHLEKTRONOV V EHLEKTROHIMICHESKIH METODAH ANALIZA". ZHurn. Analit. Himii, 10(44), 1733-1752.

[27] Mastere M.(1983). “GOMOGENNYJ KATALIZ PEREKHODNYMI METALLAMI”. M.: Mir, 300.

[28] Burke L.D.(1997). "THE ELECTROCHEMISTRY OF GOLD: I. THE REDOX BEHAVIOUR OF THE METAL IN AQUEOUS MEDIA”. Gold Bull., 2(30),43-53.

[29] Arvia A.J.(2004). "NOBLE METAL SURFACE AND ELECTROCATALYSIS. REVIEW AND PERSPECTIVES”. J. New Mat. Electrochem.System., 2(7), 133-143.

[30] Podlovchenko B.I. (2002). "EHLEKTROKATALNZ NA MODIFICIROVANNYH POLIMERAH". Uspekhi himii, 10(71), 950-965.

[31] Budnikov G.K. (1992). "HIMICHESKI MODIFICIROVANNYE EHLEKTRODY KAK AMPEROMETRICHESKIE SENSORY V EHLEKTROANALIZE” // Uspekhi himii, 6(61), 1491-1514. 
[32] Novodarova G.N. (2000). "VZAIMODEJSTVIYA O-FENANTROLINOVYH KOMPLEKSOV KOBAL'TA I MEDI S BIOHIMICHESKIMI REDOKS - SISTEMAMI”. Uspekhi himii, 6 , 67 84.

[33] Mustafa Musameh, Joseph Wang.(2002) "LOW-POTENTIAL STABLE NADH DETECTION AT CARBON-NANOTUBE-MODIFIED GLASSY CARBON ELECTRODES”. Electrochemistry Communications, 4(22), 743-746.

[34] Zen J.-M., Senthil Kumar A., Tsai D.-M. (2003). "RECENT UPDATES OF CHEMICALLY MODIFIED ELECTRODES IN ANALYTICAL CHEMISTRY”. Electroanalysis, 13(15) , 1073 1087.

[35] Aronbaev S.D. (2016). "IZGOTOVLENIE I OCENKA PRIGODNOSTI TVERDYH EHLEKTRODOV V INVERSIONNO-VOL'TAMPEROMETRICHESKOM OPREDELENII SLEDOVYH SODERZHANIJ TYAZHELYH METALLOV”.Vestnik Andizhanskogo GU, 4, 119-125.

[36] Narmaeva G.Z., Aronbaev S.D., Aronbaev D.M. (2018). "OSOBENNOSTI MODIFIKACII UGLEGRAFITOVYH EHLEKTRODOV RTUT'YU” . Materialy mezhd. nauchn.-prakt. konf. «Nauka segodnya. Real'nost' i perspektivy. Vologda, 13-15.

[37] Yao H., Sun Y., Lin X., Tang Y. (2007). "ELECTROCHEMICAL CHARACTERIZATION OF POLY(ERIOCHROME BLACK T) MODIFIED GLASSY CARBON ELECTRODE AND ITS APPLICATION TO SIMULTANEOUS DETERMINATION OF DOPAMINE, ASCORBIC ACID AND URIC ACID". Electrochimica Acta, 20(52), 6165-6171.

[38] Yaghoubian H., Karimi-Maleh H., Khalilzadeh M.A. (2009). "ELECTROCHEMICAL DETECTION OF CARBIDOPA USING A FERROCENE-MODIFIED CARBON NANOTUBE PASTE ELECTRODE”. Journal of the Serbian Chemical Society, 12(74), 1443-1453.

[39] Tan G.. Bolat G., Onur M.A., Abaci S. (2012). "DETERMINATION OF LIDOCAINE BASED ON ELECTROCATALYSIS OF A CHEMICALLY MODIFIED ELECTRODE”. Turkish Journal of Chemistry, 4(36), P. 593-600.

[40] Al-Qasmi N., Soomro M. Taliir, Aslani M. (2016). "THE EFFICACY OF THE ZNO:ALPHAFE2O3 COMPOSITES MODIFIED CARBON PASTE ELECTRODE FOR THE SENSITIVE ELECTROCHEMICAL DETECTION OF LOPERAMIDE: A DETAILED INVESTIGATION". Journal of electroanalytical chemistry, 783,112-124.

[41] Song Y.R., Wu H., Chen X.X., Shao H.B.(2002). "CYCLIC VOLTAMMETRIC RESPONSES OF NILRALE REDUCTASE ON CHEMICAL MODIFIED ELECTRODES”. Chinese Chemical Letters, 7(13), 653-654.

[42] Solak A.O., Eichorst L.R., Clark W.J., McCreery R.L. (2003). "MODIFIED CARBON SURFACES AS "ORGANIC ELECTRODES" THAT EXHIBIT CONDUCTANCE SWITCHING" . Analytical Chemistry, 2(75), 296-305.

[43] Rosie NT., Chelfi T., Hach V. (2010). "IMMOBILIZATION OF ORGANIC COMPOUNDS ON MODIFIED ELECTRODE: THE ELECTROCHEMICAL SENSOR ROUTE.” Bulletin of the Catalysis Society of India , 9, 68-73.

[44] Somanibikai S., Kadir M., Rafiq A., Kumar A. (2017). "SELECTIVE AND LOW POTENTIAL ELECTROCATALYTIC OXIDATION AND SENSING OF L-CYSTEINE USING METAL IMPURITY CONTAINING CARBON BLACK MODIFIED ELECTRODE”.Analytical methods, 9(48), 6791-6800.

[45] Badawy W.A., Ismail K.M., Medany S.S. (2011). "POLYAMINOANTLIRAQUINONE MODIFIED ELECTRODES AS ELECTROANALYTICAL SENSORS". International Journal of Electrochemical Science, 9, 4204-4217.

[46] Edwards G.A., Bergen A.J. (2007). "CHEMICALLY MODIFIED ELECTRODES". Iowa state university, 8, 296-327.

[47] Stolarczyk K., Nazaruk E., Rogalski J. (2007). "MEDIATORLESS CATALYTIC OXYGEN REDUCTION AT BORON-DOPED DIAMOND ELECTRODES" // Electrochemistry Communications, 1, 115-118. 
[48] Scavetta E., Ballarin V., Giorgetti M.(2004). "ELECTRODES MODIFIED BY ONE-STEP ELECTRO SYNTHESIS OF NI/AL-N03 DOUBLE LAYERED HYDROXIDE”. Journal of New Materials for Electrochemical Systems, 1, 43-50.

[49] Lyons M.E.G., Keeley G.P. Carbon nanotube based modified electrode biosensors. (2008). "PART 1. ELECTROCHEMICAL STUDIES OF THE FLAVIN GROUP REDOX KINETICS AT SWCNT/GLUCOSE OXIDASE COMPOSITE MODIFIED ELECTRODES”. International Journal of Electrochemical Science, 8, 819-853.

[50] Mashkour M., Rahimnejad M.,. Pourali S.M. (2017). "CATALYTIC PERFORMANCE OF NANO-HYBRID GRAPHENE AND TITANIUM DIOXIDE MODIFIED CATHODES FABRICATED WITH FACILE AND GREEN TECHNIQUE IN MICROBIAL FUEL CELL". Progress in Natural Science: Materials International, 6 (27), 647-651.

[51] Pirskij Yu.K. (2008). "MODIFICIROVANIE UGLEJ PRODUKTAMI PIROLIZA GETEROBIMETALLICHESKIH MnII /MII i ZnII/MII (M = Su, Ni) KOMPLEKSOV DLYA EHLEKTROVOSSTANOVLENIYA KISLORODA". Reports of the National Academy of Sciences of Ukraine. 1 (4), 148-154.

[52] Aronbaev S.D.,Narmaeva G.Z., Aronbaev D.M. (2018). "MODIFICIROVANNYE UGLERODNYE EHLEKTRODY: NOVYE PODHODY V KONSTRUIROVANII BIOEHLEKTROHIMICHESKIH SISTEM”.Molodoj uchenyj, 3(189), 30-31.

[53] Riquelme M.A., Lucero M.A., Villagran M. (2012). GLASSY CARBON MODIFIED ELECTRODE: POLYMER AND SUPRAMOLECULAR ASSEMBLY OF Co(II)-[TETRA(oAININOPHENYL)PORPHYRIN] NEW MATERIAL FOR ELECTROCATALYTIC ASSAYS. International Journal of Electrochemical Science, 10, 9738-9747.

[54] Rezaei-Zarchi S. (2011). "DIRECT ELECTRON TRANSFER OF MYOGLOBIN ON NICKEL OXIDE NANOPARTICLES MODIFIED GRAPHITE ELECTRODE" // Advances in Chemistry, 5(10), 3241-3248.

[55] Muresan L.M. (2011). "ZEOLITE-MODIFIED ELECTRODES WITH ANALYTICAL APPLICATIONS". Pure and Applied Chemistry, 2(83), 325-343.

[56] Aronbaev S.D., Narmaeva G.Z., Aronbaev D.M. (2017). "CYCLIC VOLTAMPEROMETRY IN THE ANALYSIS OF PHARMACEUTICAL PREPARATIONS OF ANTIHYPERTENSIVE ACTION. A MINI-REVIEW."

// Universum: Chemistry and Biology: electronic scientific journal, № 12(42). URL: http://7universum.com/ru/nature/archive/item/5257

[57] Aronbaev S.D., Narmaeva G.Z., Abdullaeva U., Aronbaev D.M. (2017). "VOLTAMMETRIC DETERMINATION OF VITAMIN B6 USING MODIFIED GLASSY CARBON ELECTRODE". Universum: Chemistry and Biology: electronic scientific journal, 11 (41). URL: http://7universum.com/en/nature/archive/item/5181 